\title{
개도국의 기후변화 취약계층에 대한 논의
}

\section{목차}

I. 서론

II. 기후변화 취약계층 정의 및 논의

1. 기후변화 취약성 정의

2. 기후변화 취약계층 정의

III. 개도국의 취약계층

1. 개도국의 기후변화로 인한 영향

2. 개도국의 취약계층 인구비율

N. 결론

참고문헌

1) · 현 한국국제협력단 연구개발팀 선임연구원 (shireen@koica.go.kr / 031-740-0565)

전 Alaska Center for Climate Assessment and Policy 연구원

알래스카 주립대학교 기후변화 정책 및 평가 박사, Ph.D. (Interdisciplinary Ph.D. in Climate Change Policy and Assessment) 


\section{I. 서론}

개도국은 선진국에 비해 기후변화에 지리적으로 취약할 뿐 아니라 사회적, 제도적인 장치의 부 재로 인해 기후변화로부터 적응능력이 부족하여 기후변화에 대해 상대적으로 취약하다. 다시 말 해, 가뭄, 홍수 등 기후변화로 인한 재해에 대해 그 영향이나 피해는 지역적 특성에 따라 그 정 도의 차이는 있으나 사회·경제적 입지가 약한 국가 및 개발도상국에 그 피해가 집중되고 있다 (DARA, 2012; Kreft et al. 2015). 문제는 이러한 피해가 그들의 국가 및 그들의 지역사회의 빈곤의 문제를 악화시키고 있으며 이는 결과적으로 개도국과 개도국의 빈곤층의 빈곤의 악순환을 초래하여 더욱 더 기후변화로 인한 취약성을 증가시키게 될 가능성이 높다(홍은경, 2014).

기후변화의 피해는 일반적으로 기후변화에 원인이 되는 국가보다는 지리적으로 기후변화에 취 약한 위치에 있는 국가와 사회·경제적으로 체제가 안정되지 못한 개도국, 그리고 그들의 빈곤계 층에 더 큰 영향을 미치며 이는 성인지적 관점에서 볼 때 여성에게도 적용된다고 할 수 있다(명 수정, 2011). UN의 인간개발보고서(UNDP, 2015)는 장기적으로 기후변화가 큰 영향을 미치며 특히 기존에 사회취약계층에 더 큰 영향을 초래할 것으로 우려하였다. 기후변화로 인한 피해는 개발도상국과 그들의 빈곤 계층의 취약성을 더 악화시키는데 따라서 여성과 장애인, 그리고 사회 각층의 소외계층에 특별한 관심을 가져야 하는 이유가 여기에 있다(UNDP, 2015).

국가 기후변화 정책수립을 위해서는 한 국가 내 기후변화 취약성에 대한 이해가 이루어져야 하며 그 지역 및 국가 내 취약계층(vulnerable group)에 대한 파악과 이들에 대한 고려가 함께 진행되어야 한다. 따라서 개도국의 기후변화 적응정책 수립을 위해서는 기후변화 영향과 취약성 에 대한 이해와 함께 각 나라에서의 기후변화에의 취약계층에 대한 파악이 필요한데 이를 통해 정책 우선순위 선정 및 지원이 결정되고, 이는 그들의 생존을 결정하는 중요한 요소일 수 있기 때문이다. 개도국에 기후변화 적응은 중요하면서도 시급한 이슈이며 이를 위하여 정확한 개도국 의 기후변화 영향 및 이들 국가 내에서도 민감하게 기후변화의 피해에 반응하는 취약계층에 대한 파악이 필요하다. 기후변화 취약계층에 대한 정의에 대해 국제사회에서 합의된 정의는 아직 존재 하지 않는 듯하나, 첫째, 특정 영향요인에 대한 노출이 심한 지역에 거주하며, 둘째, 노출에 상대 적으로 민감하게 작용하고, 셋째, 기후변화에 대해 대처능력이 떨어지는 계층으로 정의되고 있다 (하종식 외, 2014). 본 연구는 취약성 개념을 바탕으로 개도국 내 상대적으로 기후변화에 더 취 약한 그룹에 대한 파악과 그들의 기후변화로 인한 피해정도를 파악하고자 하였다.

개도국은 기후변화로부터 상대적으로 취약한 계층 비율이 더 높은 것으로 여겨진다. 그럼에도 불구하고 개도국의 취약계층에 대한 연구는 아직 충분하지 못한 것으로 여겨지며 이에 따라 본 
연구는 개도국의 취약계층에 대한 정의를 점검해보고 이에 해당되는 개도국 인구의 비율정도를 알아보고자 한다. 특히 본 연구는 개발도상국 중 24 개 중점협력국 내 취약계층의 인구비율을 파 악하여 이들의 특성을 논하고자 한다. 취약성이란 어떤 시스템이 외적영향 및 상황에 대해 영향 을 받는 정도로, 그러한 영향에 대해 얼마나 잘 대처하고, 적절한 속도로 대응하느냐에 따라 취 약성의 정도는 달라진다(홍은경, 2014). 따라서 취약성 개념에 대한 이해와 함께 개도국의 취약 계층에 대한 파악을 통해 취약성 유형과 취약계층 특성에 따른 기후변화 적응방안을 구축할 수 있게 될 것이다. 또한 이러한 연구는 각국의 정책 및 국제사회가 기후변화 적응방안을 구축하여 궁극적으로 그들이 기후변화의 영향으로부터 잘 대처하고 대응하도록 지원하는데 기초자료가 될 것이다.

\section{II. 기후변화 취약계층 정의 및 논의}

제 I 장

제 II 장

\section{1. 기후변화 취약성 정의2)}

취약성(vulnerability)의 개념은 식량안보, 자연재해 등의 분야에서 먼저 사용되었다(윤성권 외, 2013). 그 후 자연재해, 재난관리, 보건, 기후변화 등의 다양한 분야에서 조금씩 다른 의미 로 사용되었으나(유가영 외, 2008) 분야에 따라 의미와 개념이 다를 뿐 아니라(Kelly and Adger, 2000) 현재까지 전세계적으로 통용되는 개념은 없다(UNDP, 2005).

기후변화 취약성 개념은 기후변화에 대한 관심이 고조된 1990년대 초반부터 기후변화 취약성 개념에 대한 이론이 발전하기 시작하였는데(유가영 외, 2008), 기후변화 취약성 정의 역시 연구 자의 관심분야와 정책주제에 따라 통일되지 않고 다양하게 나타나며 취약성을 구성하는 요소도 조금씩 차이가 있다(고재경, 2009). 그러다가 기후변화에 관한 정부간 협의체(Intergovermental Panel on Climate Change, 이하 IPCC) 제 2차 보고서에서 기후변화 취약성 개념이 공식적으 로 처음 도입된 것으로 보이는데 일반적으로 기후변화 취약성은 '기후변화에 따른 악영향에 대처 할 수 없는 상태 또는 정도’로 정의된다(윤성권 외, 2013). $\mathrm{UNDP}(2005)$ 는 취약성에 대한 정확 한 정의가 현재 없는 실정이라고 설명하면서 '기후영향에 대한 위해성과 시스템의 취약성을 조합 함으로써 한 시스템이 기후위해에 노출되는 위험정도' 라고 정의하고 취약성을 한 시스템의 기후 변화에 대한 민감도와 적응능력의 함수로 표현하고 있다.

취약성(vulnerability) $=\mathrm{f}$ [민감도(sensitivity), 적응능력(adaptive capacity)]

2) 2.1.기후변화의 취약성 정의는 홍은경(2014)의 3. 취약성 개념 및 취약성 평가의 이론적 배경을 발췌하여 정리하였음 
기후변화 취약성 관련하여 많은 연구가 IPCC의 취약성 정의를 많이 인용하고 그 틀 안에서 취 약성 분석을 시행하고 있는데(홍은경, 2014) 기후변화 취약성 평가의 개념 및 정의는 IPCC 제2 차 평가보고서(1995) 이후 2014년까지 미세하게 변화되고 있음을 볼 수 있다(아래〈표 1〉 참 조). IPCC는 '취약성이란 기후 다양성과 극한 기후상황을 포함한 기후변화의 부정적 효과에 대한 한 시스템의 민감도 또는 대처할 수 없는 정도로서, 한 시스템이 노출되어 있는 기후 변의의 특 성, 크기, 속도, 그 시스템의 기후변화로 인한 민감도와 적응능력의 함수로 정의하고 있다(IPCC 2001, 2007). 특히 제 5 차 보고서에 나타난 취약성 정의는 기존의 제 3, 4차 보고서의 정의보다 좀 더 포괄적이며 많은 개념을 포함하고 있다.

\section{〈표 1〉IPCC의 취약성 정의}

\begin{tabular}{c|l}
\hline IPCC 보고서 & \multicolumn{1}{c}{ 취약성 정의 } \\
\hline $\begin{array}{c}\text { IPCC 2차 보고서 } \\
\text { 1995년 }\end{array}$ & $\begin{array}{l}\text { 기후변화가 시스템에 손해 혹은 손상을 끼치는 정도로 이는 그 시스템의 민감도 뿐 아니라 } \\
\text { 새로운 기후 조건에 적응할 수 있는 능력에 달려있음. }\end{array}$ \\
\hline IPCC 3, 4차 보고서 & $\begin{array}{l}\text { 기후 다양성과 극한 기후상황을 포함한 기후변화의 부정적 효과에 대한 한 시스템의 민감 } \\
\text { 도 또는 대처할 수 없는 정도로서 한 시스템이 노출되어 있는 기후 변의의 특성, 크기, 속 } \\
\text { 도, 그 시스템의 민감도와 적응능력의 함수 }\end{array}$ \\
\hline IPCC 5차년 보고서* & $\begin{array}{l}\text { 부정적인 영향을 미칠 수 있는 성향이나 경향. 취약성은 대처나 적응할 수 있는 능력을 저 } \\
\text { 2014년 }\end{array}$ \\
$\begin{array}{l}\text { 해시키거나 부족하게 만드는 민감도, 혹은 감수성(susceptibility)을 포함한 다양한 개념을 포 } \\
\text { 함함 }\end{array}$
\end{tabular}

* 5 차 보고서에서는 과학의 진보를 반영하여 4차 보고서의 취약성 다루는 범위와 관점이 다름 (IPCC, 2014) 출처: 홍은경 (2014)

현재 많은 취약성 분석은 IPCC의 정의와 개념틀(IPCC, 2001)을 사용 및 적용하고 있는데 이 는 기후변동에 대한 시스템의 노출이라는 외부적 요인과 함께 이러한 요인에 대한 민감도, 적응 능력이라는 내부적 요인을 포함하고 있기 때문이라고 여겨진다. IPCC(2001)의 취약성평가 틀 (〈그림 1〉 참조)은 기후변화 취약성을 기후노출과 시스템의 민감도를 포함하는 잠재영향 및 적응 역량의 함수로 표현하는데, 이는 아래와 같이 표현될 수 있다.

기후변화 취약성 $=\mathrm{f}($ 민감도, 노출, 적응역량 $)$

여기서 노출이란 시스템에 충격을 가하는 자극이나 영향을 의미하며, 민감도는 기후영향에 시 스템이 얼마나 민감하게 반응하는가를 의미한다. 따라서 기후변화 취약성이란 어떤 시스템의 기 후변화에 대한 잠재적 위험과 적응역량의 함수라고 할 수 있다. 
〈그림 1〉 취약성과 그 취약성 개념도

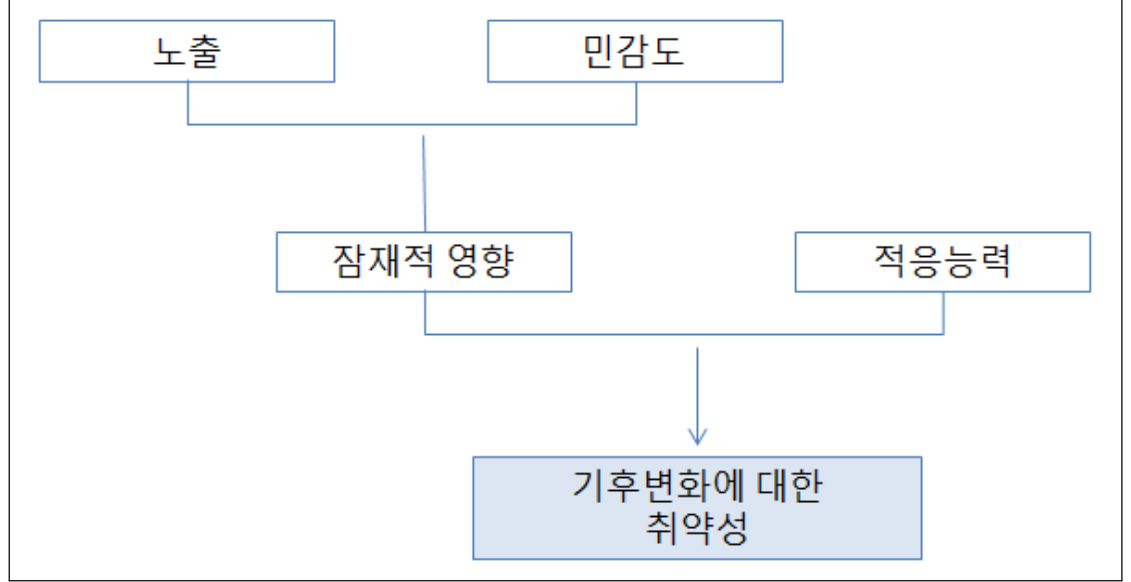

출처: IPCC (2001)

〈표 2〉은 IPCC를 비롯한 국제기구, 그리고 세계 여러 기관에서 취약성 관련 연구들이 내린 기후변화 취약성 정의를 요약한 것이다.

〈표 2〉 취약성의 정의

\begin{tabular}{|c|c|}
\hline 기관 및 연구출처 & 정의 \\
\hline IPCC & $\begin{array}{l}\text { 기후 다양성과 극한 기후상황을 포함한 기후변화의 부정적 효과에 대한 한 시스템의 민감도 또 } \\
\text { 는 대처할 수 없는 정도 }\end{array}$ \\
\hline $\begin{array}{l}\text { IPCC } \\
(2014)\end{array}$ & $\begin{array}{l}\text { 부정적인 영향을 미칠 수 있는 성향이나 경향. 취약성은 대처나 적응할 수 있는 능력을 저해시 } \\
\text { 키거나 부족하게 만드는 민감도, 혹은 감수성(susceptibility)을 포함한 다양한 개념을 포함 }\end{array}$ \\
\hline UNDP & $\begin{array}{l}\text { 기후변동이나 스트레스에 대한 노출과 이에 대한 대처 회복, 적응능력에 따른 노출단위의 위험 } \\
\text { 에 대한 민감도 }\end{array}$ \\
\hline UK CIP & $\begin{array}{l}\text { 특정 위험상황에서 야기되는 손해의 범위(IPCC의 정의를 바탕으로 하며 취약성은 시스템의 민 } \\
\text { 감도뿐 아니라 적응 능력에 의해서도 결정됨) }\end{array}$ \\
\hline UNFCCC & $\begin{array}{l}\text { 사회 인구 생물종 생태계 지역 농업시스템이나 그 외 다른 시스템이 기후변화의 역효과에 민감 } \\
\text { 한 정도 또는 대처할 수 없는 정도 }\end{array}$ \\
\hline UN/ISDR & $\begin{array}{l}\text { 물리적 사회적 경제적 환경적 요소나 과정에 의해 결정되는 조건으로 위험의 영향에 대한 지역 } \\
\text { 사회의 민감성을 증가시킴 }\end{array}$ \\
\hline $\begin{array}{c}\text { Australian } \\
\text { Greenhouse } \\
\text { Office }\end{array}$ & $\begin{array}{l}\text { 자연계와 인간사회가 기후변화 다양성 극한 기후상황의 부정적 영향에 대처할 수 없는 범위/ } \\
\text { 시스템이나 사회의 민감도 적응능력 뿐만 아니라 기후변화에 의해서도 좌우됨 }\end{array}$ \\
\hline $\begin{array}{l}\text { E. Tomkins } \\
\text { (2005) }\end{array}$ & $\begin{array}{l}\text { 개인이나 집단 시스템이 위험이나 스트레스에 노출되어 나타나는 위험과 그에 대한 대처 회복 } \\
\text { 적응능력에 대한 민감성 }\end{array}$ \\
\hline
\end{tabular}




\begin{tabular}{c|l}
\hline $\begin{array}{c}\text { 기관 및 연구출처 } \\
\begin{array}{c}\text { Pew Center } \\
\text { (2004) }\end{array}\end{array}$ & 기후변화에 대한 시스템의 민감도 측정지표로, 시스템의 노출, 민감도, 적응 능력의 함수 \\
\hline 미국 에너지부 & $\begin{array}{l}\text { 기후변화에 대한 시스템 혹은 과정의 민감도(기후 투입 변화에 따른 결과 혹은 특성의 변화 정 } \\
\text { 도)와 시스템의 적응성(변화가 새로운 조건을 활용할 수 있는 정도) }\end{array}$ \\
\hline $\begin{array}{c}\text { Blaikie et al. } \\
\text { (1994) }\end{array}$ & 자연재해의 영향에서 회복할 수 있는 정도를 포함한 개인이나 집단의 노출 \\
\hline $\begin{array}{c}\text { Kelly and } \\
\text { Adger(2000) }\end{array}$ & \begin{tabular}{l} 
개인이나 사회집단이 생계와 복지에 영향을 주는 외부적 스트레스에 대처하하고 회벖본 능력멱 \\
\hline Brooks 적응할
\end{tabular} \\
\hline
\end{tabular}

출처: 홍은경 (2014)

\section{2. 기후변화 취약계층 정의}

\section{가. 기후변화 취약계층 국내 정의}

기후변화 취약계층에 대해 아직 국내·국제적으로 합의되어 통용되는 정의는 없지만 국내외 많 은 연구들은 기후변화의 영향에 대해 좀 더 민감하게 반응하는 취약계층에 대해 각각의 개념으로 정의하여 필요한 정책을 제안하고 있는 듯하다. 특히 국내 연구의 경우 기후변화 적응정책 제안 에 앞서 선행과제로 기후변화 취약계층에 대한 정의와 특성에 관한 연구가 국내 기관 및 다른 나 라에 비해 활발하게 이루어 졌는데, 일반적으로 기후변화 취약계층은 (1) 특정 기후노출이 심한 지역에 거주하며, (2) 기후노출에 상대적으로 민감하게 반응하고, (3) 해결능력이 떨어지는 계층으 로 정의된다(하종식 외, 2014). 
〈표 3〉기후변화 취약계층 관련 정의

\begin{tabular}{|c|c|}
\hline 저자 & 정의 \\
\hline 신호성 (2009) & $\begin{array}{l}\text { 기후변화에 취약한 지역에 사는 사람, 사회적 배제 집단(빈곤층, 허약집단, 이동성 장애집 } \\
\text { 단, 취약거주집단 등), 기후변화 정보 - 지원서비스 - 의사결정구조에서 배제된 집단 }\end{array}$ \\
\hline $\begin{array}{l}\text { 왕광익 외 (2010); } \\
\text { 이진희, 왕광익 (2013) }\end{array}$ & $\begin{array}{l}\text { 기후변화에 노출되어 있는(기후노출) 계층 중 특히 기후변화에 따른 영향에 민감하게 반응 } \\
\text { 하고(민감도),이에 대응할 수 있는 능력(적응능력)이 낮은 계층 }\end{array}$ \\
\hline $\begin{array}{l}\text { 신호성 외 (2010); } \\
\text { 추장민 외 (2010) }\end{array}$ & $\begin{array}{l}\text { 저소득계층, 이동성 장애집단, 취약 거주집단, 기후변화 정보 및 서비스, 의사결정 구조에 } \\
\text { 서 배제된 집단 등 대체적으로 특정 기후변화에 약한 빈곤층인 동시에 사회적 배제 계층 } \\
\text { 으로 간주 }\end{array}$ \\
\hline 명수정 외 (2012) & 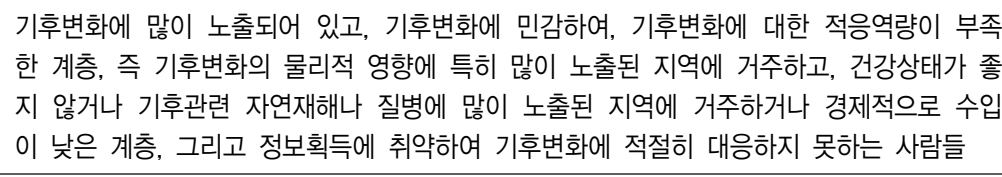 \\
\hline 임영신 외 (2013) & $\begin{array}{l}\text { 육체적, 정신적 장애를 갖거나, 사회경제적 지위가 낮아 기후변화 영향(폭염, 한파, 집중호 } \\
\text { 우 및 태풍, 폭설, 가뭄, 홍수 등)에 자력으로 대응하기 어려운 사람으로 노인이나 어린이, } \\
\text { 장애인, 기초생활수급자, 농민(축산과수농민 등), 옥외근로자 등이 해당. 또한, 지리적으로 } \\
\text { 기후변화에 취약한 지역(저지대, 상수도 미보급지역, 상습침수지역 등)에 거주하여 지속적 } \\
\text { 인 피해를 받는 계층이 포함 }\end{array}$ \\
\hline
\end{tabular}

출처: 이진희, 왕광익 (2013) p.17

상기 〈표 3〉은 국내 선행연구 중 기후변화 취약계층의 개념을 정리한 것이다. 표의 내용을 통해 알 수 있듯이, 기후변화 취약계층은 기후변화 영향 그 자체의 심각정도의 문제가 아닌 그 영향을 받는 개인 또는 집단의 능력 차이에 따른 취약정도의 차이라고 할 수 있다(하종식 외, 2014).

\section{〈표 4〉기상이변 영향별 중점 취약계층}

\begin{tabular}{|c|c|}
\hline 영향 & 중점 취약계층 \\
\hline 폭염 & $\begin{array}{l}\text { 생활 기반환경이 폭염기후에 노출이 상대적으로 많은 기후변화에 대한 적응 및 대처 능 } \\
\text { 력이 부족한 계층 }\end{array}$ \\
\hline 가뭄, 한파 & 기후변화 영향에 민감한 거주 · 지리적 환경이 거주하는 경제적 빈곤계층 \\
\hline 폭설 & $\begin{array}{l}\text { 65세 이상 노인 및 장애인 등 야외활동에 제약이 따르면 개인별 기후변화에 대한 } \\
\text { 적응능력이 부족한 계층 }\end{array}$ \\
\hline 태풍, 집중호우 & 거주 및 지리적 취약계층에 거주하여 풍수해 피해에 대처할 능력이 부족한 계층 \\
\hline
\end{tabular}

출처: 하종식 외 (2014)

상기 〈표 4〉는 우리나라에서 기후학적 자연재해의 종류에 따른 취약계층을 분류한 것이다. 앞 으로 미래의 기상현상에 대해서는 그 빈도 및 강도가 강해질 것으로 예측되고 있는 바(IPCC, 2011) 향후 기상이변 종류에 따른 각 취약계층에 대한 파악과 이들의 적응 및 대응 능력 향상을 위한 제도적 장치가 요구된다. 


\section{나. 기후변화 취약계층 국외 정의}

$\mathrm{IPCC}$ 제 5 차 보고서에서는 비기후적 요인과 불공정한 개발과정에서 나타난 불평등으로 인해 기후변화의 취약성과 노출에 차이가 발생하여 사회 - 경제 · 문화 - 정치 등으로부터 소외된 사람들 이 기후변화의 적응과 완화작용에 취약함이 존재한다고 설명하고 있다(IPCC, 2014). 이는 기후 변화 취약계층을 지적하는 내용이라고 사료되기는 하나 국외연구 역시 기후변화 취약계층에 대한 합의된 정의가 없는 듯하다. 단지 국제사회에서 기후변화 취약계층에 대해서는 '기후변화 취약계층 을 취약한 그룹(vulnerable groups)' 혹은 '기후변화 영향에 더 취약한 사람들(more vulnerable to climate change impacts)'로 표현하고 있다. 기후변화 영향관련 보고서와 자료들을 종합해보 면 외국 자료의 경우 다음과 같은 사람들을(group) 기후변화 취약계층으로 보고 있다.

\section{1) 아동}

기본적으로 인간의 건강은 주변의 물리적 환경 조건에 영향을 받는다. 물리적, 심리적, 인지적 미성숙으로 인해 특히 아동들은 환경변화에 더 취약하며 그 대표적인 예가 기후변화라고 할 수 있다. 기후변화가 심해짐에 따라 기후변화로부터 위험은 더 증가할 것이고, 아동들의 기후변화로 인한 피해는 더 심각해질 것으로 예상된다.

〈그림 2〉기후변화와 아동에게 미치는 영향

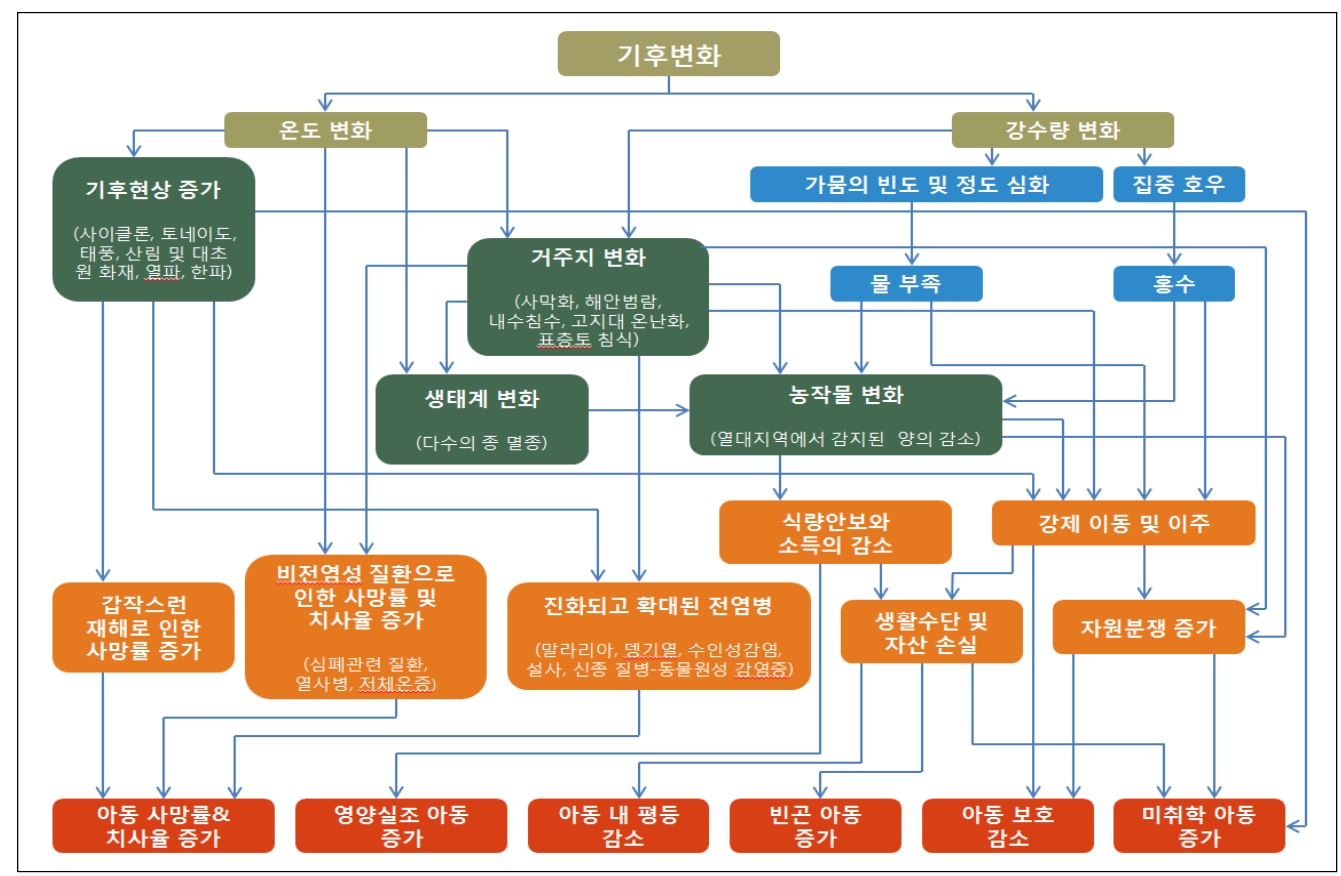

출처: UNICEF UK (2008) 
상기 〈그림 2〉은 기후변화의 여러 가지 영향이 아동에게 미치는 영향을 다각화 한 것이다. 이 를 통해 기후변화는 아동의 교육, 주거부터 인권, 건강, 보건, 나아가 생명을 위협하는 등 기후변 화로 인한 아동의 영향은 상당하다고 하겠다.

특히 기후변화로 야기된 가뭄, 홍수 같은 재해로 인해 발생한 식량문제는 아동의 영양섭취에 직접적인 영향을 끼치며, 수인성 감염 등 전염병으로 인한 보건 및 건강 문제는 아동들의 생명과 직결되는 중대한 문제라고 할 수 있다. 따라서 기후변화 취약계층을 논하는데 있어서 아동은 반 드시 고려되어야 하는 핵심 취약계층이며 이들에 대한 국제사회의 우선적 관심과 논의가 요구된다.

\section{2) 노인}

노인의 경우 아동계층과 같이 물리적인 주변환경의 변화에 민감하게 반응하는 계층이다. 특히 개발도상국 내 노년층은 일반적으로 신체적, 경제적으로 젊은 세대에 비해 대응능력이 없는 상태 로 보이는데 이는 건강상태, 수입원, 지리학적위치, 가족부양능력, 공공보건시설의 접근성 정도 에 따라 다르게 나타나기도 한다.

〈그림 3〉기후변화로 인한 노년층의 피해

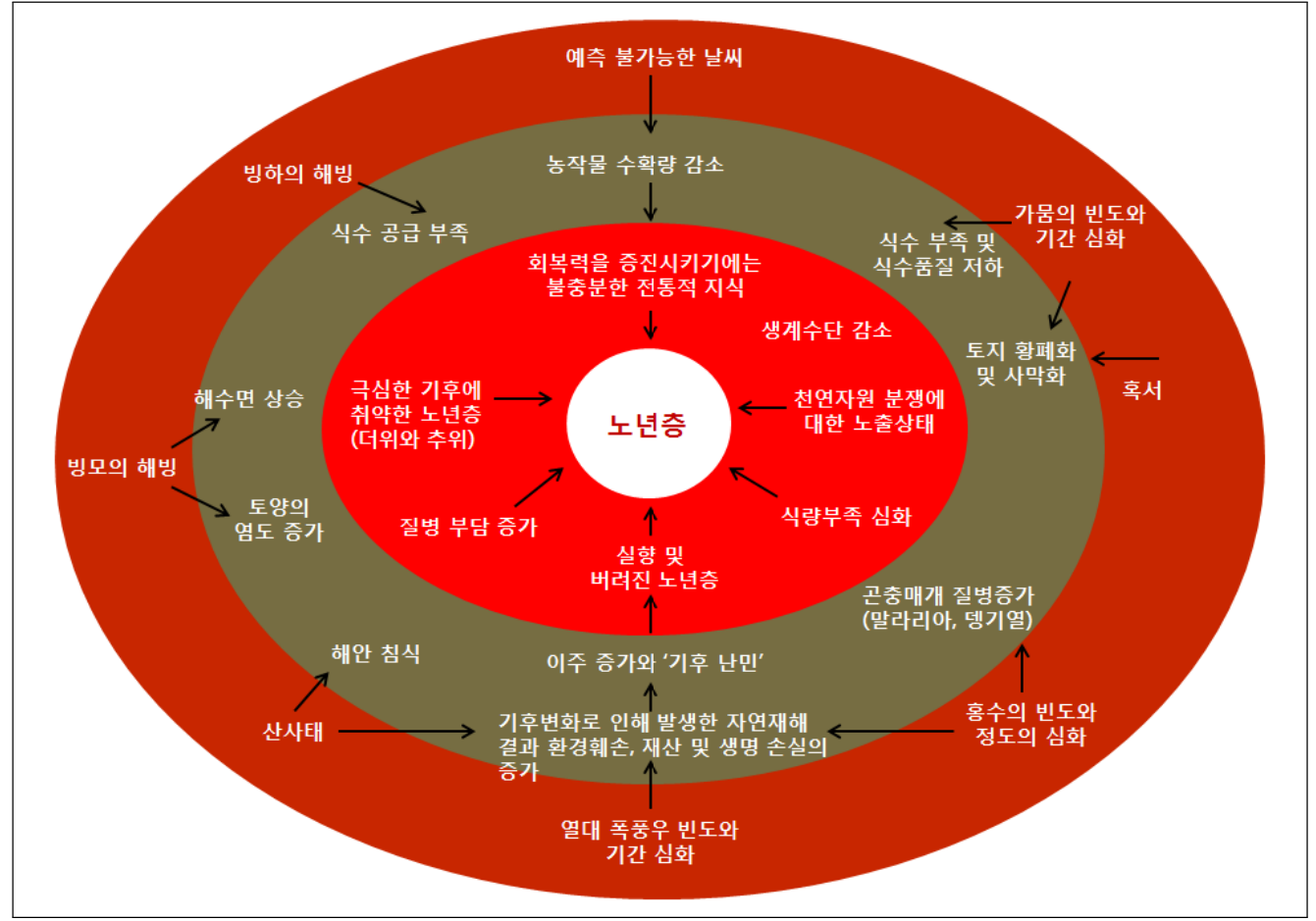

출처: Helpage (2008) 
상기 〈그림 3〉은 기후변화로 인한 노년층의 피해를 기후변화로 인한 재해의 종류별로 살펴본 것이다. 앞서 설명한 바와 같이 신체적, 경제적으로 젊은 세대에 비해 대응능력이 없는 상태인 노년층의 경우 기후변화로 인해 질병, 건강악화와 같은 건강 보건의 문제가 야기 될 수 있으며, 생계수단의 감소 및 삶의 터전 상실로 인한 생계의 위협, 빈곤 악화 등과 같은 사회적 문제가 발 생 또는 악화 될 수 있다. 따라서 이들에게 사회의 정보 및 제도로부터 고립되지 않고 기후변화 로부터 대응할 수 있도록 국제사회의 관심과 각 국에서의 적응 대책 마련이 요구된다.

\section{3) 여성}

기후변화 현상은 전지구적으로 나타나고 있지만 그 피해는 특정계층에 가혹하게 나타나기도 하는데 대표적인 예가 기후변화로 인한 여성의 피해라고 여겨진다. 가정에서 가족을 보살피고 영 양을 공급하는 책임을 지는 것이 일반적인 여성의 개도국 내의 사회경제적인 역할로 보여지며 따 라서 홍수 및 가뭄과 같은 극단적 자연재해는 여성에게 더욱 가혹한 상황이 될 수 있다. 특히 여 성은 극단적인 자연재해에 대해 생존할 수 있는 기술이나 훈련을 제대로 받지 못해 피해가 더 커 지는 경향이 있는데(명수정, 2011), 아래〈표 5〉의 서술들은 지난 20여 년간 발생한 대표적인 전세계 기후재난 및 재해가 여성에게 더 위협적인 결과를 가져왔음을 보여준다.

\section{〈표 5〉기후변화와 여성의 피해}

- 자연재해가 발생하였을 시, 여성과 아동은 남성에 비해 사망할 경우가 14 배 높음

- 1991 년 방글라데시에서 발생한 14 만 명의 사상자를 기록하였는데 40 대 이상 여성의 비율이 사상치의 $30 \%$ 를 차 지함

- 2004년 아시아 지역에서 발생한 쓰나미의 경우, 사망자의 $70 \%$ 이상의 여성이었음

- 2005년 미국 뉴 올리언스를 강타한 허리케인 카트리나는 이미 가장 빈곤하고 소외된 지역사회에서 생활하는 아프 리카계 미국여성에게 가장 큰 영향을 미침

- $87 \%$ 의 미혼 여성과 $100 \%$ 의 기혼여성이 2008 년 미얀마 아예야르와디 델타지역에 상륙한 사이클론 나르기스로 인 해 주 수입원을 잃음

출처: WEDO (2008)

아래의 〈표 6〉은 기후변화로 인한 각각의 분야별 파급효과 및 영향, 그리고 이것이 여성에 미 치는 직간접 파급효과를 요약해 놓은 것이다. 이를 통해 기후변화는 다양한 분야에 영향을 미치 며 또한 여성의 삶은 기후변화의 다양한 영향에 대해 직간접적인 피해를 많이 보고 있음을 알 수 있다. 특히 기후변화가 초래하는 여러 가지 영향은 전반적으로 여성의 삶의 질 저하와 사회경제 적인 활동의 제약, 결과적으로 생계수단의 상실 등 더 큰 어려움을 초래하게 된다. 이처럼 한 나 라에서 일어나는 기후변화 현상은 여성에게 더 가혹하며 이는 여성 빈곤과 연결되는 등 한나라에 
서 정의롭지 못하는 상황이 생겨나게 되는데 이를 해결하기 위한 각 나라에서의 노력 뿐 아니라 국제사회에서의 관심 및 지원이 필요하다.

\section{〈표 6〉기후변화와 이로 인한 여성에 대한 직간접 영향}

\begin{tabular}{|c|c|c|}
\hline 분야 & 기후변화의 파급효과 및 영향 & 여성에 대한 기후변화의 직간접 파급효과/영향 \\
\hline $\begin{array}{l}\text { 천연자원: } \\
\text { 식량, 식수, } \\
\text { 연료 \&토지 }\end{array}$ & $\begin{array}{l}\text { - 기상이변과 불규칙한 날씨로 인한 가뭄 } \\
\text { 및 홍수 } \\
\text { - 토양 비옥도 감소 } \\
\text { - 작물 수확량 감소 및 흉작 } \\
\text { - 자원 부족 } \\
\text { - 안전하고 깨끗한 식수의 부족 }\end{array}$ & $\begin{array}{l}\text { - 물을 기르고 음식과 뗄감을 구해오는 등 가사노동에 소요 } \\
\text { 되는 시간과 부담의 증가 (때때로, 이는 낮은 학교 등록율, } \\
\text { 식자율 그리고 조혼으로 이어짐) } \\
\text { - 여성의 열량섭취부족과 기아 증가 } \\
\text { - 오염된 물에 노출 } \\
\text { - 토지소유권이 없는 경우, 비옥한 토지 소유 권리를 박탈 } \\
\text { - 전통적인 토지 보유 체계의 상실 }\end{array}$ \\
\hline 자연재해 & $\begin{array}{l}\text { - 해수 온난화 } \\
\text { - 날씨 및 계절의 변화 } \\
\text { - 불규칙하고 극심해진 날씨로 인한 기후 } \\
\text { 현상 }\end{array}$ & $\begin{array}{l}\text { - 날씨에 대한 정보 접근성 및 교육의 부족 } \\
\text { - 제한된 재해 대응력 (때때로, 여성은 남성이 동행하지 하지 } \\
\text { 않으면 외출 불가) } \\
\text { - 수영, 나무 오르기와 같은 생존기술을 남자아이들은 정기적 } \\
\text { 으로 배우고 숙련하는 반면 여자아이들은 이러한 생존기술 } \\
\text { 을 익히지 못 하였을 뿐만 아니라 익숙지 않음 } \\
\text { - 재난복구 시 의사결정의 단계에 있어 여성은 주로 배제됨 }\end{array}$ \\
\hline 건강 & $\begin{array}{l}\text { - 수인성 및 매개성 전염병의 증가 } \\
\text { 예) 기후상승과 빈번한 폭풍으로 인한 } \\
\text { 말라리아 증가가 원인 } \\
\text { - 더위 관련 질병 } \\
\text { - 영양실조 } \\
\text { - 대기오염, 알러지, 천식 증가 } \\
\text { - 불안 및 우울증과 같은 정신질환 }\end{array}$ & $\begin{array}{l}\text { - 나이와 관계없이 임신 및 수유하는 여성은 건강을 위협하는 } \\
\text { 요소들로부터 그 어느 사람보다 취약한 상태에 놓이게 됨 } \\
\text { - 재해 지구 내 면역, 가족계획, 생식 건강 등의 의료서비스 } \\
\text { 부족으로 인한 상황 악화 } \\
\text { - 보호 결핍으로 인한 산모와 영아의 사망률 증가 } \\
\text { - 대피소/피난처 내 임신, 수유, 월경 중인 여성을 위한 위생 } \\
\text { 용품 및 위생 서비스의 부족 }\end{array}$ \\
\hline 인구 성장 & $\begin{array}{l}\text { - 기후변화가 극심한 지역과 천연자원을 } \\
\text { 주 생계수단으로 취하는 인구가 거주하 } \\
\text { 는 지역의 인구 성장 }\end{array}$ & $\begin{array}{l}\text { - 시간의 경과에 따라 점점 소진되는 정부 자원과 천연자원 } \\
\text { 에 대한 경쟁 심화 } \\
\text { - 여성은 가장 취약한 계층의 하나로 여전히 위험에 처해있음 } \\
\text { - 빈번한 출산으로 인한 여성의 건강악화 }\end{array}$ \\
\hline 도시화 & $\begin{array}{l}\text { - 환경의 황폐화, 낮아진 생산성 그리고 } \\
\text { 자원 관련 분쟁으로 인한 농촌에서 도 } \\
\text { 시로의 이주 증가 } \\
\text { - 비공식적 피난처 및 비공식 지역사회의 } \\
\text { 확대 }\end{array}$ & $\begin{array}{l}\text { - 식수와 위생이 된, 전반적으로 건강을 위협하는 위험성이 } \\
\text { 높은 지역에 주로 정착 } \\
\text { - 도시 내 공인된 시장(markets)은 남성에게 혜택을 주는 경 } \\
\text { 향이 있음 } \\
\text { - 가난한 도시여성의 경우 의료서비스에 대한 접근이 미비 } \\
\text { - 도시빈곤의 악화 }\end{array}$ \\
\hline $\begin{array}{c}\text { 이주 \& } \\
\text { 거주지박탈 }\end{array}$ & $\begin{array}{l}\text { - 재해는 일시적이거나 혹은 영구적인, 국 } \\
\text { 내 혹은 국제적인 이주로 이어질 가능 } \\
\text { 성 있음 } \\
\text { - 환경의 황폐화와 자원을 두고 벌이는 } \\
\text { 분쟁은 여성과 남성 모두의 이주를 촉 } \\
\text { 진함 } \\
\text { - 지역의 잠재적 위험으로 인한 강제이주 }\end{array}$ & $\begin{array}{l}\text { - 여성은 전 세계 이주민의 최소 절반을 차지함에도 불구하 } \\
\text { 고, 그들의 요구는 이주정책의 우선순위에서 고려되고 있지 } \\
\text { 않음 } \\
\text { - 여성은 이주하기에 필요한 자원을 충분히 갖추지 못하였거 } \\
\text { 나, 재해가 발생하였을 시 이에 대처 할 자원을 갖추고 있 } \\
\text { 지 못함 } \\
\text { - 강제이주는 여성의 취약성을 심화시키고 생계수단 및 자원 } \\
\text { 에 대한 이미 부족한 현재의 접근성을 더욱 악화 }\end{array}$ \\
\hline
\end{tabular}

제 I 장

제 II 장

섹

터

제표장

제 $\mathbb{N}$ 장 


\begin{tabular}{|c|c|c|}
\hline 분야 & 기후변화의 파급효과 및 영향 & 여성에 대한 기후변화의 직간접 파급효과/영향 \\
\hline 가구 구성 & $\begin{array}{l}\text { - 이주, 거주지박탈 혹은 자연재해로 인한 } \\
\text { 사망으로 가구 구성의 변화 및 손실 }\end{array}$ & $\begin{array}{l}\text { - 여성 가구주 가구의 증가 } \\
\text { - 복구/보험 프로그램 내 여성 가구주 가구를 위한 자원은 } \\
\text { 한정적이거나 자원은 남성을 우선수위로 두고 배분 } \\
\text { - 토지권의 결핍은 여성의 식량환보와 생계를 위협 } \\
\text { - 성별에 따른 노동 분화의 심화 } \\
\text { - 여성의 높은 재난사망률로 인한 가구 내 여성의 수 감소 }\end{array}$ \\
\hline $\begin{array}{c}\text { 분쟁 \& } \\
\text { 폭력 }\end{array}$ & $\begin{array}{l}\text { - 한정된 자원을 두고 벌이는 경쟁은 분 } \\
\text { 쟁과 이재를 발생시킬 가능성이 있음 } \\
\text { - 불규칙한 강우량과 천연자원의 결핍은 } \\
\text { 내전 발생가능성을 } 50 \% \text { 까지 끌어올림 } \\
\text { - 생계수단 불안정으로 인한고충 및 불안 } \\
\text { 증가 }\end{array}$ & $\begin{array}{l}\text { - 분쟁은 현존하는 성 불평등을 증폭시킴 } \\
\text { - 남성은 전투를 통해 부상을 입거나 사망하는 경우가 많은 } \\
\text { 반면, 여성은 강간, 폭력, 불안, 우울증과 같은 분쟁의 다른 } \\
\text { 결과물로부터 고통 받음 } \\
\text { - 가정 내 혹은 재난 대피처 내 존재하는 높은 폭력성 }\end{array}$ \\
\hline
\end{tabular}

출처: WEDO (2008)

\section{4) 원주민}

천연자원에 의존하고 환경과 밀접한 관계를 맺고 있는 원주민은 기후변화가 끼치는 영향을 직 접적으로 받게 되는 것으로 알려져 있는데 이미 원주민으로서 겪는 정치적 그리고 경제적 소외, 토지와 자원의 약탈, 인권침해, 차별과 실업 등과 같이 이미 많은 어려움을 겪고 있는 이들에게 기후변화는 그들의 삶을 더욱 악화시키는 것으로 알려져 있다. 아래의 〈표 7〉은 전세계 원주민의 기후변화가 원주민에게 미치는 다양한 영향을 요약해 놓은 것이다.

\section{〈표 7〉 기후변화와 원주민}

- 해발고도가 높은 히말라야 지역 내 빙하의 용해는, 단기적으로 많은 양의 물이 공급되는 결과를 나았지만, 빙하와 눈의 양이 점점 줄어듦에 따라 장기적으로 보았을 때 물의 공급은 적어질 것으로 예상됨

- 기후변화의 영향으로 아마존 내 산림 벌채와 산림 분열이 발생되었는데, 이 발생으로 인해 대기에 배출되는 탄소 량은 증가하여 결과적으로 기후변화의 속도를 가속화하는 동시에 기후변화의 영향도 심화될 것으로 예상됨. 그 예 로, 2005년에 발생한 가뭄은 결국 아마존 서부지역의 화재로 이어졌는데 산림이 사바나로 교체되는 현 시점(상황) 으로 보아 위와 같은 화재는 다시 발생될 것으로 예상되며 해당 지역의 소수민족들의 생계수단에 막대한 영향을 미칠 것으로 예상됨

- 북극지역의 토착민들은 북극곰, 바다코끼리, 바다표범, 순록 등의 사냥 및 낚시를 통한 채집활동에 의존하고 있음. 기후변화로 인해 전통적인 식자원인 포유류의 종류 그리고 포유류의 채집 가능량이 줄어들고 있음. 기상예측의 부 정확성, 수시로 변화하는 날씨에 따른 빙하 이동으로 인한 이동 안전성 역시 낮아져 소수민족의 식량확보, 건강 외 신체에도 위협을 가하고 있음

- 핀란드, 노르웨이, 그리고 스웨덴의 겨울 철 따뜻해진 날씨는 순록의 주 음식자원인 이끼의 성장을 저해하며 순록 은 충분한 이끼를 섭취하지 못함. 이로 인해 많은 수의 순록이 사망하였는데, 순록이 생활수단, 경제, 그리고 문화 의 한 축까지 차지하는 Saami 공동체에 악영향을 끼침

출처: UN (2008) 
상기 설명한 바와 같이 전세계 원주민의 삶은 기후변화로 인한 직간접 피해로 인해 많은 어려 움을 겪고 있으며 기후변화 심화 정도에 따라 향후 그 피해가 더 증가할 것으로 여겨진다. 아래 〈표 8〉은 원주민의 취약성을 정도를 요인을 사회적/생물물리학적 요인으로 나누어 살펴본 것으 로 원주민의 기후변화로 인한 보호를 위해 이들의 장애요인 (취약성요인)에 대한 원인과 대책에 대한 고려가 필요하다.

〈표 8〉 원주민의 취약성 요인

\begin{tabular}{|c|c|}
\hline $\begin{array}{l}\text { 사회적 취약성 } \\
\text { 요인(원인) }\end{array}$ & $\begin{array}{l}\text { - 빈곤과 불평등 } \\
\text { - 보건과 영양 } \\
\text { - 사회적 연결망(사회적 자본) } \\
\text { - 소외: 정보, 기술, 영향력에서의 궁핍 } \\
\text { - 다각화된 생계수단 } \\
\text { - 토지 보유 및 청구권 }\end{array}$ \\
\hline $\begin{array}{c}\text { 생물물리학적 취약성 } \\
\text { 요인(원인) }\end{array}$ & $\begin{array}{l}\text { - 극한 상황에 대한 노출 } \\
\text { - 천연자원의 이용가능성 } \\
\text { - 안전한 식수와 땔감의 확보 } \\
\text { - 생물다양성의 이용가능성 } \\
\text { - 거주지 } \\
\text { - 주택의 품질 } \\
\text { - 토지 이용과 토지 피복의 변화 }\end{array}$ \\
\hline
\end{tabular}

\section{III. 개도국의 취약계층 (24개 중점협력국 중심으로)}

\section{1. 개도국의 기후변화로 인한 영향}

우리정부는 2010년「국제개발협력 선진화 방안」을 통해 유·무상 중점협력국 26개국을 선정 하고, 중점협력국에 대해 전체 $\mathrm{ODA}$ 의 $70 \%$ 이상을 집중적으로 지원한다는 정책적 방향을 수립 하였다. 하지만 2015년 3월 국내외 원조환경 변화 등을 반영하여 24개로 재조정하였는데 (관계 부처 합동, 2015) 그 국가는 아래〈표 9〉와 같다. 
〈표 9〉우리나라 유·무상 ODA 통합 중점협력국

\begin{tabular}{c|l}
\hline 지역 & \multicolumn{1}{c}{ 중점협력국 } \\
\hline 아시아(11개국) & $\begin{array}{l}\text { 베트남, 인도네시아, 캄보디아, 필리핀, 방글라데시, 몽골, 라오스, } \\
\text { 네팔, 스리랑카, 파키스탄, 미얀마 }\end{array}$ \\
\hline 아프리카(7개국) & 가나, 에티오피아, 모잠비크, 르완다, 우간다, 탄자니아, 세네갈 \\
\hline $\begin{array}{c}\text { 중동, 독립국가연합(Commonwealth } \\
\text { of Independent States, CIS)(2개국) }\end{array}$ & 우즈베키스탄, 아제르바이잔 \\
\hline 중남미(4개국) & 콜롬비아, 페루, 볼리비아, 파라과이 \\
\hline
\end{tabular}

출처: 관계부처합동 (2015)

24 개 중점협력국의 지역적 분포를 보면 아시아에 11 개국으로 가장 많이 집중되어 있으며, 아 프리카 7 개국, 중남미 4 개국, 중동, 독립국가연합 2 개국이 각각 그 뒤를 따르고 있다.

아래〈표 10〉은 2005년부터 2014년 사이에 24개 중점협력국의 기후 관련한 재해(기후학적 요소, 수문학적 요소, 기상학적 요소)로 인한 피해정도를 정리한 것이다. 이 자료를 토대로 볼 때 2005년부터 2014년 사이에 기후 관련한 재해가 768건이 발생하였으며 이로 인하여 186,495 명 이 사망하고 281 백만명이 피해를 입었다. 세가지 기후관련 지표 중에 수문학적 피해가 가장 두 드러지는데 이 기간 동안 510 번 발생하였으며 이로 인해 22,527 명이 사망, 129 백만명이 피해를 입었다. 기상학적요소로 인한 피해는 수문학적 피해 다음으로 높은 것으로 보이는데 같은 기간 동안 217 번 발생하였으며 이로 인해 163,876 명이 사망, 112 백만명이 피해를 입었다.

국가별로 보면 기후변화 관련 재해발생은 필리핀이 가장 많았으며(167건), 그 다음이 인도네 시아(95건), 베트남(72건), 방글라데시(57건)가 그 뒤를 따르고 있다. 2005년부터 2014년 사이 에 기후 관련한 재해로 인한 사망자수는 미얀마가 가장 많고(138,760명) 그 다음으로 필리핀 (17,849명), 방글라데시(7,219명), 파키스탄(6,477명)이 뒤를 따르고 있다. 2005년부터 2014년 사이에 기후 관련한 재해로 인한 전체피해자는 필리핀이 가장 많으며 $(97,521,885$ 명 $)$ 그 뒤를 파 키스탄(44,431,785명), 방글라데시(42,013,516명), 에티오피아(22,216,469명)가 따르고 있는데 24개 중점협력국 중 주요 피해(빈도수, 사망자, 피해자수 모두 고려)는 아시아 지역이 다른 지역 보다 훨씬 많이 집중되어 있음을 알 수 있다.

2005년부터 2014년 동안 24개 중점협력국에 피해를 큰 피해를 주었던 기후관련 재해는 수문 학적 요소(홍수, 폭풍해일, 연안침수 등)로 이는 중점협력국 대상 기후변화 적응활동을 위한 국제 사회의 지원은 수문학적 재해 상황에 미리 대처하는데 초점을 두고 이를 고려하여 사업이 설계되 어야 함을 내포하고 있다. 


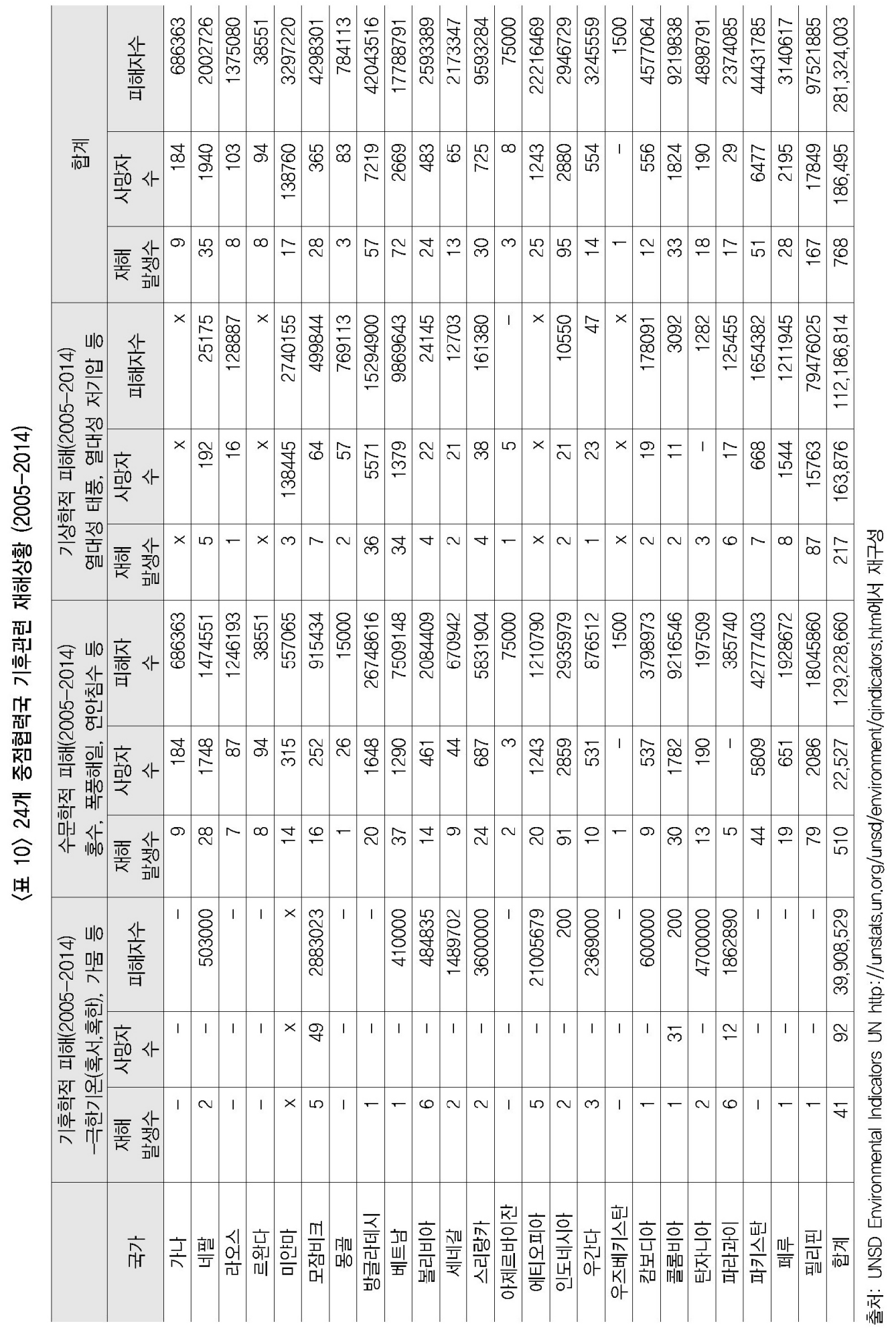


German Watch는 2006년부터 매년마다 기후변화로 인한 총사망자수, 인구 10 만 명당 사망 자수, 피해 금액과 GDP 대비 피해 금액의 비중, 이 네 가지 지표를 바탕으로(〈표 11 참조〉) 각 국가별 기후위기지표(Climate Risk Index: CRI)를 발표하고 있는데 아래〈표 12〉는 German Watch의 CRI 전체 결과 표에서 우리나라 24개 중점협력국의 CRI 순위 및 각각 지표의 세부내 용을 정리한 것이다. CRI는 다른 취약성 평가와 달리 기후변화로 인해 재산이나 사람에게 실질 적인 피해를 준 재해의 결과로만 되어 있어 기후변화 재해로 인한 종합적인 지표라기에는 다소 무리가 있다(홍은경, 2014). 그럼에도 불구하고 이 표를 통해 24개 중점협력국 중 기후변화로 인 한 상당한 인명피해와 재산피해를 입는 대부분의 국가가 아시아 국가임을 알 수 있는데, 다시 말 해 기후변화로 인한 재해가 아시아에 편중되어 있음을 알 수 있다. 이는 앞의 〈표 10〉에서 살펴 본 바와 같이 2005년부터 2014년 동안 24개 중점협력국의 기후변화 관련 피해가 아시아 지역에 훨씬 많이 집중되어 있다는 데이터 분석과 일치한다.

〈표 11〉2016년 German Watch 지표구성 및 가중치

\begin{tabular}{c|c}
\hline 지표 & 가중치 \\
\hline 사망자수 & $1 / 6$ \\
\hline 인구 10만명 당 사망자수 & $1 / 3$ \\
\hline 손실액(구매력환율 기준) & $1 / 6$ \\
\hline GDP 당 손실 & $1 / 3$ \\
\hline
\end{tabular}

출처: Kreft et al. (2015) 


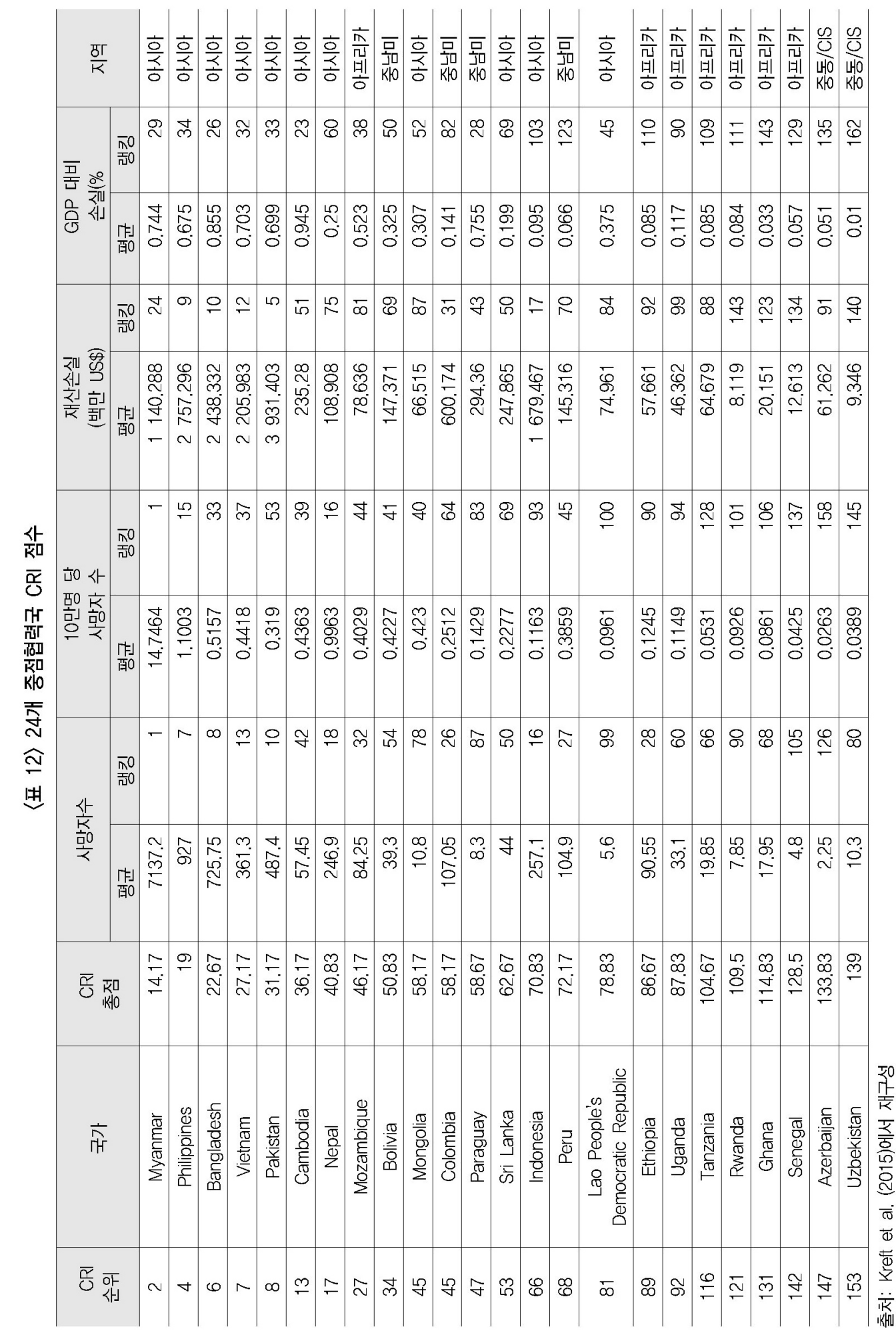


아래〈표 13〉과〈표 14〉는 우리나라 24개 중점협력국이 속한 4개의 지역(대륙)에 대해 기후 변화로 인한 영향을 정리한 것이다.

〈표 13〉 기후변화로 인한 아프리카와 아시아의 영향

\begin{tabular}{|c|c|}
\hline 지역(대륙) & 기후변화로 인한 영향 \\
\hline 아프리카 & 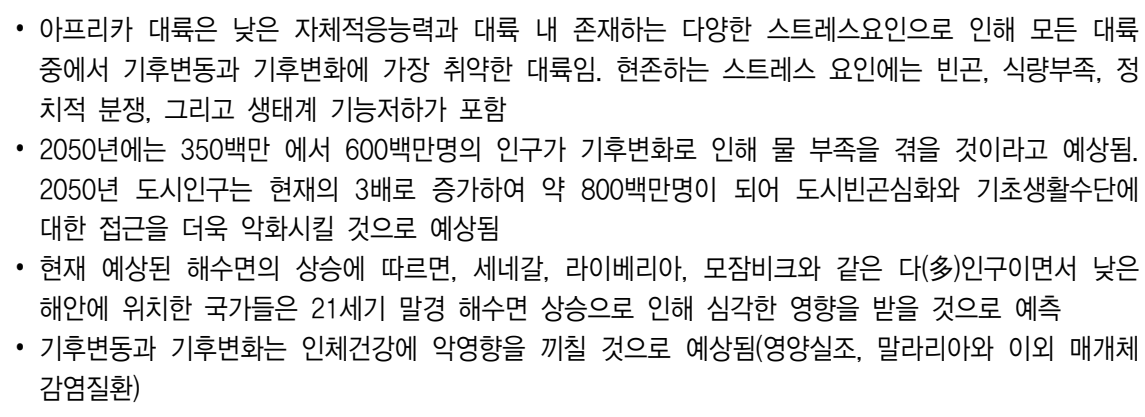 \\
\hline 아시아 & 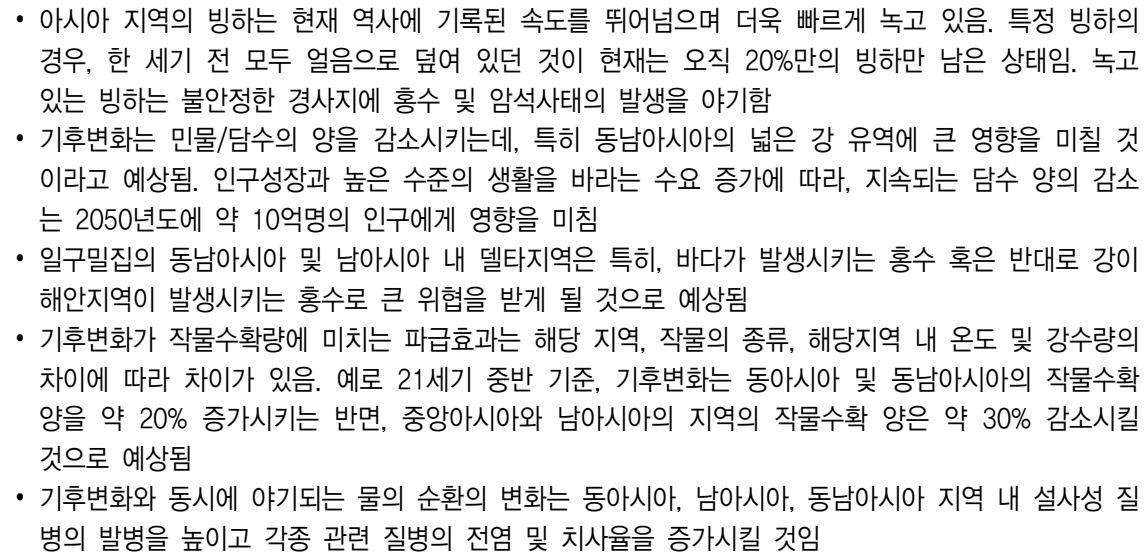 \\
\hline
\end{tabular}

출처: WEDO (2008) 
〈표 14〉 기후변화로 인한 유럽과 중남미의 영향

\begin{tabular}{|c|c|}
\hline 지역(대륙) & 기후변화로 인한 영향 \\
\hline & $\begin{array}{l}\text { - 기후변화의 광범위한 파급효과는 이미 유럽대륙 내에서 확인된 사안으로, 녹는 빙하, 해수면 상승, } \\
\text { 작물의 성장시간 증대(longer growing seasons), 작물 종의 범위 이동(species range shifts), 열파 } \\
\text { 관련 건강 악화와 같은 파급효과가 포함되어 있음 } \\
\text { - 기후변화는 미래에 유럽 내 거의 모든 국가의 사회, 인프라, 건강상태에 부정적인 영향을 미칠 것으 } \\
\text { 로 보인다. 농업과 에너지를 포함한 여러 경제 부문의 어려움이 예상됨 } \\
\text { - 중앙 및 동유럽의 강수량의 향후 감소는 미래 심각한 물 부족으로 이어질 것이라고 보인다. 임지생산 } \\
\text { 력(forest productivity) 또한 감소할 것으로 보여 이탄지역(peatland)의 화재가 증가할 것으로 예상됨 }\end{array}$ \\
\hline 중남미 & $\begin{array}{l}\text { - 금세기 중반 내에, 온도 상승과 토양 수분 감소로 인해 아마조니아 동쪽의 열대 산림이 사바나로 교 } \\
\text { 체될 것으로 예상됨 } \\
\text { - 건조한 지역에 발생하는 기후변화는 가뭄을 더욱 심화시키며 염류화 작용(염분의 양 증가)을 야기하 } \\
\text { 거나 농지의 사막화(토지 황폐화)를 야기할 것으로 보임. 옥수수 및 커피를 비롯한 주요 작물 외 가 } \\
\text { 축의 생산성이 몇 개의 지역에서 감소되며 식량안전에 부정적인 영향을 끼칠 것으로 예상됨. 온대지 } \\
\text { 역의 경우, 콩 수확의 증가가 예상됨 } \\
\text { - 해수면 상승은 홍수의 발생률을 인상시켜 많은 인구의 이주를 야기하고, 식수의 염류화로 인한 해안침식을 } \\
\text { 가능하게 함. 위와 같은 위험 증가로 인해 어류자원과 오락 및 관광산업은 악영향을 받을 것이라고 예측 } \\
\text { - 녹는 빙하와 강수량의 변화는 농업활동, 에너지 발전 그리고 인구가 소비 가능한 물의 양에 큰 위협 } \\
\text { 을 줄 것으로 예상됨 } \\
\text { - 기후변화와 토지사용의 변화는 여러 종의 동식물의 멸종 속도를 증가 } \\
\text { - 따뜻해진 날씨, 춥지 않은 겨울, 강수량의 변화는 모기로 통해 전염되는 치군군야 바이러스와 같은 } \\
\text { 매개체 감염 질병의 발생을 높임 }\end{array}$ \\
\hline
\end{tabular}

출처: WEDO (2008)

전 세계에 걸친 4 개의 대륙에 대한 기후변화의 피해는 다양한 원인으로 인하여 그 피해정도도 다양하게 나타날 것으로 예상되는데 그로 인한 파급효과는 자연환경의 변화, 동식물, 식량, 주민 의 보건 및 건강 등에 직간접적으로 영향을 미칠 것으로 예상된다.

\section{2. 개도국의 취약계층 인구비율}

아래〈표 15〉은 24 개 중점협력국의 전체 인구 중 기후변화로부터 취약한 계층의 비율을 보여 준다. 본 연구에서는 여성, 아동, 노인, 그리고 원주민을 기후변화에 취약한 계층으로 보았는데 한 국가 내 전체여성의 인구, 4세미만의 아동(남.여), 65 세 이상 노인인구(남·여)를 그 해당계층 으로 보았다. 그 결과 〈표 15〉에서 보듯이 24개 중점협력국의 기후변화로부터 취약한 계층비율 은 56.8\%-62.8\% 사이로 나타났다. 계층비율은 각개 나라별 차이가 크게 나지 않는 것으로 보 이나 지역별 구분하여 비교하였을 때는 아프리카 지역이 전반적으로 다소 높은 것으로 보인다. 〈표 15〉에서 보듯이 24개 중점협력국 중 아프리카 국가의 경우는 7 개 국가 중 가나를 제외한 6 개 국가 모두 최빈개도국(Least Developed Countries)인데 앞서 설명한 바와 같이 기후변화의 피해는 선진국보다 개도국, 특히 최빈개도국에 더 크게 민감하게 나타난다는 사실에 비추어 볼 때 아프리카 지역 국가와 취약계층의 영향은 실제로 더 클 것으로 예상된다. 
〈표 15〉에서 백분율로 나타낸 기후변화 취약계층 인구비율은 원주민은 고려되지 않았는데 이 는 원주민 인구 자료가 나이와 성별로 구분되어 있지 않았기 때문에 원주민 인구를 포함했을 경 우 중복 산정될 가능성이 있기 때문에 포함시키지 않았다. 원주민 인구 자료에 있어서는 자료 및 데이터 확보가 용이하지 않아 24개 국가에 대해 정보를 찾을 수가 없었으나 그럼에도 불구하고 〈표 15〉가 보이는 바와 같이 몇 개의 나라의 경우(예: 네팔, 라오스, 인도네시아) 전체 인구 중 원주민이 차지하는 인구비율이 상당히 높다. 따라서 기후변화 취약계층으로 원주민까지 고려하였 을 경우 상기 표에서 나타난 $56.8 \%-62.8 \%$ 보다 높을 것으로 사료된다.

〈표 15〉24개 중점협력국 취약인구 비율

\begin{tabular}{|c|c|c|c|c|c|c|c|}
\hline 국가 & 년도 & 전체인구 & $\begin{array}{c}\text { 취약계층 } \\
\text { 비율* }\end{array}$ & 지역 & $\begin{array}{c}\text { 소득 } \\
\text { 유형** }\end{array}$ & $\begin{array}{c}\text { 원주민 } \\
\text { 인구 }\end{array}$ & $\begin{array}{c}\text { 원주민 } \\
\text { 비율 }\end{array}$ \\
\hline 네팔 & 2001 & $22,736,934$ & $57.4 \%$ & 아시아 & LDC & $8,500,000$ & $37.4 \%$ \\
\hline 라오스 & 2005 & $5,621,982$ & $56.8 \%$ & 아시아 & LDC & $2,000,000$ & $35.6 \%$ \\
\hline 몽골 & 2010 & $2,754,685$ & $58.3 \%$ & 아시아 & LMIC & & \\
\hline 미얀마 & 2014 & $50,279,900$ & $57.1 \%$ & 아시아 & LDC & & \\
\hline 방글라데시 & 2011 & $144,043,697$ & $57.8 \%$ & 아시아 & LDC & $3,000,000$ & $2.1 \%$ \\
\hline 베트남 & 2009 & $85,846,997$ & $59.2 \%$ & 아시아 & LMIC & $13,000,000$ & $15.1 \%$ \\
\hline 스리랑카 & 2001 & $16,929,689$ & $58.3 \%$ & 아시아 & LMIC & 4,510 & $0.0 \%$ \\
\hline 인도네시아 & 2010 & $237,641,326$ & $58.3 \%$ & 아시아 & LMIC & $70,000,000$ & $29.5 \%$ \\
\hline 캄보디아 & 2008 & $13,395,682$ & $57.5 \%$ & 아시아 & LDC & 400,000 & $3.0 \%$ \\
\hline 파키스탄 & 2003 & $138,979,270$ & $57.2 \%$ & 아시아 & LMIC & & \\
\hline 필리핀 & 2010 & $92,335,113$ & $58.7 \%$ & 아시아 & LMIC & $18,400,000$ & $19.9 \%$ \\
\hline 가나 & 2010 & $24,658,823$ & $60.3 \%$ & 아프리카 & LMIC & & \\
\hline 르완다 & 2002 & $8,128,553$ & $58.7 \%$ & 아프리카 & LDC & 35,000 & $0.4 \%$ \\
\hline 모잠비크 & 2007 & $20,252,223$ & $62.8 \%$ & 아프리카 & LDC & & \\
\hline 세네갈 & 2013 & $12,873,601$ & $61.6 \%$ & 아프리카 & LDC & & \\
\hline 에티오피아 & 2007 & $73,750,932$ & $62.0 \%$ & 아프리카 & LDC & $15,000,000$ & $20.3 \%$ \\
\hline 우간다 & 2002 & $24,442,084$ & $61.2 \%$ & 아프리카 & LDC & 26,700 & $0.1 \%$ \\
\hline 탄자니아 & 2012 & $44,928,923$ & $59.3 \%$ & 아프리카 & LDC & & \\
\hline 볼리비아 & 2012 & $10,059,856$ & $57.0 \%$ & 중남미 & LMIC & $2,800,000$ & $27.8 \%$ \\
\hline 콜롬비아 & 2005 & $41,468,384$ & $57.4 \%$ & 중남미 & UMIC & $1,450,000$ & $3.5 \%$ \\
\hline 파라과이 & 2002 & $5,163,198$ & $58.9 \%$ & 중남미 & LMIC & 112,848 & $2.2 \%$ \\
\hline 페루 & 2007 & $27,412,157$ & $58.5 \%$ & 중남미 & UMIC & $3,360,331$ & $12.3 \%$ \\
\hline 아제르바이잔 & 2014 & $9,477,119$ & $58.4 \%$ & 중동 & UMIC & & \\
\hline 우즈베키스탄 & 2014 & $30,757,669$ & $57.8 \%$ & 중동 & LMIC & & \\
\hline
\end{tabular}

* 취약계층의 비율은 전체 여성의 인구, 4 세미만의 아동(남.여), 65 세 이상 노인인구(남.여)를 그 해당계층으로 보고 이를 백 분율로 표시(65세 이상의 여성 노인인구와 전체 여성의 인구가 중복산정되지 않도록 한번만 포함함)

** 24개 중점협력국 소득유형별 분류는 DAC List of ODA Recipients를 참조하여 분류 https://www.oecd.org/dac/stats/documentupload/DAC\%20List\%20of\%200DA\%20Recipients\%202014\%20final.pdf LDC: Least Developed Countries

LMIC: Lower Middle Income Countries and Territories(per capita GNI \$1046-\$4125 in 2013)

UMIC: Upper Middle Income Countries and Territories(per capita GNI \$4126-\$12745 in 2013)

인구자료 출처: http://data.un.org/Data.aspx?d=POP\&f=tableCode\%3A22

원주민자료 출처: 홍은경 (2014) 


\section{IV. 결론}

기후변화는 전 지구적으로 영향을 미치지만 높은 소득과 안정적인 시스템과 제도를 가지고 있 는 선진국은 개발도상국에 비해 기후변화 대응능력이 높기 때문에 기후변화로 인한 취약정도가 상대적으로 낮다고 할 수 있다. 더구나 개도국은 1 차 자연자원에 의존하는 경제구조를 가지고 있 으며 많은 인구가 해안지역에 집중적으로 분포하고 있어 기후변화로 인한 기상재해로부터 피해가 더 크게 나타나고 있다(이희연, 2014). 그럼에도 불구하고 기상재해로부터 예방 및 경고체계에 대한 대응을 위한 예산과 정책이 제한적인 상황이므로 개도국은 기후변화에 대해 여전히 취약한 상황이다.

본 연구에서는 기후변화로 취약성과 기후변화로 인해 더 취약한 계층을 개도국 중심으로 고려 하여 알아보았다. 특히 24개 중점협력국을 중심으로 고려하여 24개 중점협력국 내 기후변화 취 약인구의 비율 정도를 알아보았다. 기후변화는 평균기온 및 해수면 상승과 같은 장기적 변화 뿐 만 아니라 홍수, 태풍, 가뭄과 같은 극한 자연재해의 증가로 빈곤계층을 더욱 빈곤하게 만들 수 있다(명수정, 2011).

그런데 기후변화의 피해는 선진국보다 개도국, 특히 최빈개도국에 더 크게 민감하게 나타난다. 따라서 기후변화의 최전선에 있는 개도국 및 기후변화 취약국에 대한 지원이 확대되어야 한다. 한 국가 내에서도 기후변화 현상에 대해 지역에 따라 미치는 영향이 다르고 그 나라 안에서도 사 회적 취약계층이 더 큰 영향을 받게 된다. 본 연구에서는 여성, 노인, 아동 그리고 원주민을 개 도국 내 기후변화 취약계층으로 보고 24 개 중점협력국 내 기후변화의 인구정도를 살펴보았다. 24 개 중점협력국의 기후변화로부터 취약한 계층비율은 $56.8 \%-62.8 \%$ 사이로 각각 나라별 백분 율 차이가 크게 나지 않는 것으로 보인다. 단지 지역구분에 있어서 아프리카 지역의 경우 취약인 구 비율이 다른 지역의 국가보다 다소 높은 것으로 나타났다. 우리나라 24 개 중점협력국 중 아프 리카 7 개 국가 중 6 개 국가가 최빈개도국이다. 앞서 설명한 바와 같이 기후변화의 피해는 선진국 보다 개도국, 특히 최빈개도국에 더 크게 민감하게 나타난다. 따라서 아프리카 지역의 경우 국가 전체의 인구 중 많은 인구가 기후변화 영향에 대해 더 민감하게 피해를 입을 수 있다.

기후변화 피해는 개발도상국 전체 뿐 아니라 각 나라의 빈곤층, 그리고 그 나라의 기후변화 취 약계층에 추가적인 부담으로 작용하게 될 것이다. 개발도상국이 선진국에 비해 기후변화에 취약 할 뿐 아니라 추가적으로 향후 경제성장과 도시화가 진전될 것으로 예상되기 때문에(이희연, 2014) 이들의 기후변화를 통한 피해정도와 부담은 악화될 것이다. 특히 향후 미래 기후변화가 악화될 경우, 개도국과 그 취약계층 빈곤의 악순환이 초래될 뿐 아니라 기후변화로 인한 취약성 
이 증가될 가능성이 높다. 따라서 기후변화에 취약한 계층과 나라(지역)의 적응 능력 제고를 위 한 적절한 자원배분과 이들을 위한 적응 대책수립과 함께 이들의 적응능력을 증진시키기 위한 선 진국들의 지원, 즉 개도국과 이들의 기후변화 취약계층의 기후변화 적응을 위한 선진국의 지원이 요구된다. 


\section{〈참고문헌〉}

고재경. 2009. “경기도 기후변화 취약성 평가 연구”. 경기: 경기개발원

관계부처합동. 2015. “ODA 중점협력국 재조정(안)". 제 21차 국제개발협력위원회. 의결 안건(제 $21-1$ 호)

명수정. 2011. “기후변화에 대응하는 국제사회 노력”.「젠더리뷰」 2011 가을호. Vol.22.

서울: 한국여성정책연구원

유가영·김인애. 2008. “기후변화 취약성 평가지표의 개발 및 도입방안”. 서울: 한국환경 정책평가연구원

윤성권·최봉석·정의찬. 2013. “시흥시 기후변화 취약성 평가 연구”. 「한국기후변화학회 지」Vol.4(1). 2013. pp.1-10

이진희·왕광익. 2013. “취약계층을 배려한 녹색도시정책 방향”. 「국토정책 Brief」. 2013.7. 경기: 국토연구원

이희연. 2014. “개발도상국의 기후변화 취약성 실태와 기후변화 대응 과제”.「환경논총」 제 53권. pp.95-101

하종식 외. 2014. "기후변화 취약계층 지원 · 관리 체계화”. 서울: 한국환경정책평가연구 원, 세종: 환경부

DARA. 2012. "Climate Vulnerability Monitor 2: a Guide to the Cold Calculus of a Hot Plane,” available at http://www.daraint.org/wp-content/uploads/2012/ 10/CVM2-Low.pdf. (접속일: 2016.11.05.)

Helpage. 2009. "Witness to Climate Change: Learning from older people's experience," available at https://www.ifa-fiv.org/wp-content/uploads/2012/ 12/059_Climate-Change-and-Older-People.pdf (접속일: 2016.11.05.)

IPCC. 2001. "Climate Change 2001: Synthesis Report. A Contribution of Working Groups I, II and III to the Third Assessment Report of the Intergovernmental Panel on Climate Change”. Cambridge: Cambridge University Press

2007. "Climate Change 2007: Impacts, Adaptation and Vulnerability. Contribution of Working Group II to the Fourth Assessment Report of the IPCC". Cambridge: Cambridge University Press 
2011. "Human Health and Climate Change: Impacts, Adatpation and Vulnerability”. Cambridge: Cambridge University Press . 2014a. "Climate Change 2014 : Impacts, Adaptation, and Vulnerability Summary for Policymakers". Cambridge: Cambridge University Press 2014b. "Climate Change 2014: Impacts, Adaptation, and Vulnerability, Contribution of Working Group II to the Fourth Assessment Report of the IPCC". Cambridge: Cambridge University Press

IUCN. 2008. "Indigenous and Traditional Peoples and Climate Change Issues Paper," available at https://cmsdata.iucn.org/downloads/indigenous_peoples_ climate_change.pdf (접속일: 2016.11.05.)

KARAT. 2012. "Climate Change: Women in developing countries, the hardest hit," available at http://www.karat.org/wp-content/uploads/2012/02/Briefon-Gender-and-climate-change.pdf (접속일: 2016.11.05.)

Kelly, P. M., and Adger, W. N., 2000. "Theory and practice in accessing vulnerability to climate change and facilitating adaptation”. Climate Change 47: $325-52$

Sönke K., David E., Lukas D., and Fischer L. 2015. “Global Climate Risk Index 2016," available at https://germanwatch.org/fr/download/13503.pdf (접속일: 2016.11.05.)

UN. 2008. "Climate change and indigenous peoples" presented in United Nations Permanent Forum on Indigenous Issues, held from 21st April to 2nd May, 2008 in New York, available at http://www.un.org/en/events/indigenousday/ pdf/Backgrounder_ClimateChange_FINAL.pdf (접속일: 2016.11.05.)

UNDP. 2015. "Human Development Report 2015: Work for Human Development," available at http://hdr.undp.org/sites/default/files/2015_human_development_ report_1.pdf (접속일: 2016.11.05.)

UNICEF UK. 2008. "Our climate, our children, our responsibility: The implications of climate change for the world's children”. UNICEF UK Climate Change Report 2008, available at https://www.crin.org/en/docs/climatechange.pdf (접속일: 2016.11.05.)

WEDO. 2008. "Climate Change Connections.” available at http://www.uncclearn.org/ sites/default/files/inventory/unfpa201.pdf (접속일: 2016.11.05.) 